Tropical Journal of Pharmaceutical Research, December 2009; 8 (6): 521-530

(C) Pharmacotherapy Group Faculty of Pharmacy, University of Benin,

Benin City, 300001 Nigeria.

All rights reserved.

Research Article

Available online at http://www.tjpr.org

\title{
Radioprotective and In-Vitro Cytotoxic Sapogenin from Euphorbia neriifolia (Euphorbiaceae) Leaf
}

\author{
Papiya Bigoniya* ${ }^{* 1}$ and Avtar Chand Rana ${ }^{2}$ \\ ${ }^{1}$ Radharaman College of Pharmacy, Radharaman Group of Institutes, Ratibad, Bhopal, M.P. 462002, \\ ${ }^{2}$ B.N College of Pharmacy, B.N Group of Colleges, Udaipur, Rajasthan, India.
}

\begin{abstract}
Purpose: Euphorbia neriifolia Linn. (Euphorbiaceae) plant is traditionally used in the treatment of abdominal troubles, bronchitis, tumours, leucoderma, piles, inflammation, and enlargement of spleen. The objective of this study was to evaluate the antioxidant and anticancer activities of a sapogenin isolate of this plant.

Methods: Euphol was isolated as a major constituent from the triterpenoidal sapogenin fraction of $E$. neriifolia leaf. Its in-vitro antioxidant activity was evaluated by reducing power assay, 1,1 - diphenyl -2 picryl hydrazyl (DPPH) assay, as well as hydroxyl radical and superoxide radical scavenging activities. Radioprotective activity was assessed against radiation-induced chromosomal aberrations and cytotoxicity on murine $F_{1} B 16$ melanoma.

Results: The sapogenin exerted moderate antioxidant activity with highly significant $(p<0.001)$ reduction of gamma radiation-induced chromosomal aberrations (33.5\% compared to $71.5 \%$ for radiation treatment alone at $4 \mathrm{~Gy})$. It also exhibited cytotoxic activity on melanoma cell lines $\left(\mathrm{IC}_{50}=\right.$ $173.78 \mu \mathrm{g} / \mathrm{ml})$.

Conclusion: The sapogenin fraction showed antioxidant, radioprotective and cytotoxic activities. This study provides a scientific basis for the claimed traditional anticarcinogenic potentials of E. neriifolia.
\end{abstract}

Keywords: Euphorbia neriifolia; Euphol; Sapogenin; Antioxidant; Radioprotective; Melanoma; Chromosomal aberration

*Corresponding author: E-mail: p_bigoniya2@hotmail.com; Tel: +91-0755-2477941 (Res), 0755-2896237 (Inst); Fax: $+91-0755-2896663$ 


\section{INTRODUCTION}

Euphorbia neriifolia Linn, belonging to the family, Euphorbiaceae, is found throughout the Deccan Peninsula of India and commonly occurs in the dry hilly rocky grounds of north, central and south India. It is a herb full of spine, and is popularly known as sehund or thohar in Hindi. Ayurveda describes the plant as bitter, pungent, laxative, carminative, improves appetite, as well as useful in abdominal problems, bronchitis, tumours, loss of consciousness, delirium, leucoderma, piles, inflammation, enlargement of spleen, anaemia, ulcers and fever. Its leaves, in the Indian traditional system, are used as aphrodisiac, diuretic, and also in cough and cold, bleeding piles and ano-rectal fistula [1].

Plants of euphorbia species show anticarcinogenic activity due to the presence of several terpenes, anthocyanins, alcohols and steroids; diterpenoid ingenol 3,20dibenzoate and phorbol 12-tiglate 13decanoate isolated from Euphorbiaceae plants show antileukaemic activity against the P-388 lymphocytic leukaemia in mice [2]. Euphol, a triterpene alcohol from the roots of Euphorbia kansui, has inhibitory activity against mice skin tumour [3].

E. neriifolia, being widely available in large quantities, is potentially a low-cost source of active therapeutic substances. We have previously reported on the mild CNS depressant, wound healing and immunomodulatory activities of the hydroalcohol leaf extract [4-6]. Little phytopharmacological work, however, has been done on the medicinal application of the leaf. Saponin isolated from the leaf possesses good haemolytic and in-vitro antioxidant activity but it is devoid of antibacterial activity up to $10 \mathrm{mg} / \mathrm{ml}$ concentration [7]. Since ethnopharmacological exploration has shown the traditional use of $E$. neriifolia, especially its leaf, as antitumour agent, the objective of this study was to isolate sapogenin from the plant's leaf and study its antioxidant and anticancer activities.

\section{EXPERIMENTAL}

\section{Plant material}

E. neriifolia leaves were collected from cultivated field hedge plants in the suburban areas of Bhopal (latitude $23.21^{\circ}$, longitude $77.84^{\circ}$, BHOP), Madhya Pradesh, India, in September 2005. The plant was identified with the aid of available literature and authenticated by $\operatorname{Dr}$ AP Shrivastava, a taxonomist and Principal, P.K.S Govt. Ayurveda College and Institute, Bhopal, India. A voucher specimen (no. 1085) was deposited in the herbarium of the department.

\section{Reagents}

RPMI 1640 media, foetal calf serum and 1,1 - diphenyl -2-picryl hydrazyl (DPPH) were purchased from Sigma Chemicals Co., St. Louis, USA while phytohaemagglutinin was obtained from Difco, USA. Collagen-coated culture flasks were purchased from Nunc, Denmark. and Neubauer hemocytometer from Feinoptik, Germany. Modified Eagle Minimum Essential Media and deoxyribose were purchased from Himedia, Mumbai; vincristin from Cipla, India, nitroblue tetrazolium from E. Merck, Darmstadt, Germany. Photomicrographs were captured using an Olympus $D \times 60$ microscope connected to an Olympus DP-50 digital camera.

\section{Extraction, isolation and characterization of compound}

One kilogram of the dried powder of the leaf was extracted with $3 \mathrm{~L}$ of cold ethanol $(70 \%)$ by maceration for seven days and the solvent removed under vacuum. Phytochemical investigation of the extract was performed to detect the presence of reducing sugar, tannin flavonoid, alkaloid, saponin, steroid, glycoside and fixed oil $[8,9]$. The extract was 
re-suspended in $250 \mathrm{ml}$ of water and $500 \mathrm{ml}$ of chloroform in $\mathrm{HCl}(50 \% \mathrm{v} / \mathrm{v})$ was added to effect acid hydrolysis of its saponins content in order to isolate sapogenins. The chloroform phase was separated and concentrated at $<40{ }^{\circ} \mathrm{C}$ to a third of its volume. This phase was exhaustively extracted with water-saturated n-butanol (three times) and the solvent removed under vacuum. The brown dried powder obtained represents the total crude sapogenin (yield: $2.41 \%$ ) and it tested positive according to Salkowski and Noller's test [10].

\section{Characterisation of sapogenin isolate}

The whole sapogenin isolate was subjected to column chromatography on silica gel using chloroform, a solvent gradient of chloroform/ethyl acetate (80:20, 60:40, 40:60 and 20:80), ethyl acetate and methanol. Five fractions were collected and chromatographed on silica gel $\mathrm{G}$ plates using $\mathrm{CHCl}_{3}$ : $\mathrm{MeOH}$ (50:50). Fraction 3 was subjected to other assessments including Salkowski, Noller's and Libermann Burchard tests [10]. Its melting point was determined from its DSC thermogram using a Mettler Toledo DSC 821 system in which the sample presssealed in an aluminium pan with a perforated lid and heated at a rate of $5^{\circ} \mathrm{C} / \mathrm{min}$ in a nitrogen environment. The UV spectra of 5 $\mu \mathrm{g} / \mathrm{ml}$ sapogenin fraction in chloroform were obtained with a Shimadzu (UV-1700 Pharmaspec) spectrophotometer while the IR spectra were recorded on a Shimadzu (Jasco FTIR-5300) spectrometer using $\mathrm{KBr}$ pellet at a scanning speed of $2 \mathrm{~mm} / \mathrm{sec}$ and with resolution set at $4 \mathrm{~cm}^{-1}$. NMR spectra were determined with a Bruker Deltonics (Avance 300) spectrometer in $\mathrm{CDCl}_{3}$ at $300 \mathrm{MHz}$ and the entire chemical shifts were relative to tetramethyl silane (TMS, $\delta$ 0.00). The electron-impact mass spectra of the powdered sample was recorded on Shimadzu (QP 5000) spectrometer in $\mathrm{CHCl}_{3}$, injected in HT-8 column, using helium as the carrier gas at a heating rate of $15 \circ \mathrm{C} / \mathrm{min}$ and scan rate of $1 \mathrm{scan} / \mathrm{sec}$ in a scan range of 100-500 Delton.

\section{Preparation of extract stock solutions}

A stock solution of the total sapogenin (50 $\mathrm{mg} / \mathrm{ml}$ ) was prepared in dimethyl-sulfoxide (DMSO) and the volume made up to $1000 \mathrm{ml}$ (to obtain a $100 \mu \mathrm{g} / \mathrm{ml}$ concentration) with RPMI media (for blood culture) or Eagle's Modified MEM (for melanoma cell culture). It was then sterilized by filtration through a 0.2 $\mu \mathrm{m}$ membrane filter. Other concentrations, ranging from $40-75 \mu \mathrm{g} / \mathrm{ml}$, were prepared by dilution. The final DMSO concentration of extract media combination was $0.25 \% \mathrm{v} / \mathrm{v}$ and at this level, no growth inhibitory effects were observed.

\section{In-vitro antioxidant activities}

In-vitro antioxidant activities of the total sapogenin were measured in a concentration range of $50-1000 \mu \mathrm{g} / \mathrm{ml}$, using various methods.

\section{Reducing power assay}

The reducing power assay (RPA) involves the oxidation-reduction reaction of potassium ferricyanide and ferric chloride in the presence of the antioxidants. The reducing power of $1 \mathrm{mg}$ sample is equivalent $(E)$ to reducing power of $1 \mathrm{nM}$ ascorbic acid (AS) expressed as ASE/mg assayed following the method of Oyaizu [11]. Different concentrations of the sapogenin and $1 \mathrm{nM}$ of ascorbic acid in a final volume of $1 \mathrm{ml}$ were taken in different test tubes and mixed with $500 \mu \mathrm{l}$ of potassium ferricyanide (1\%). The mixture was incubated at $50{ }^{\circ} \mathrm{C}$ for $20 \mathrm{~min}$. TCA $(10 \%, 50 \mu \mathrm{l})$ was added and centrifuged at $600 \mathrm{rpm}$ for $10 \mathrm{~min}$. To the supernatant, $0.5 \mathrm{ml}$ of ferric chloride $(0.1 \%)$ was added and the absorbance of the resultant violet coloured solution was measured at $700 \mathrm{~nm}$.

\section{Hydrogen-donating ability}

Hydrogen-donating ability (HDA) was measured as the amount of total sapogenin required for inhibiting the formation of 1,1diphenyl -2-picryl hydrazyl (DPPH) radical by 
$50 \%\left(\mathrm{IC}_{50}\right.$ value $)$ according to the method of Hatano et al [12]. Antioxidants react with methanolic DPPH $(100 \mu \mathrm{M})$ and convert it to 1,1-diphenyl -2-picryl hydrazine. Different concentrations of the sapogenin $(200 \mu \mathrm{l})$ was added to $3 \mathrm{ml}$ of methanolic DPPH; $20 \mathrm{~min}$ later, the amount of DPPH remaining was measured spectrophotometrically at $520 \mathrm{~nm}$ against blank.

\section{Hydroxyl radical scavenging ability}

Hydroxyl radical scavenging ability (HRSA) was measured by evaluating the competition between deoxyribose and the test compounds for hydroxyl radicals generated from the $\mathrm{Fe}^{3+} /$ ascorbate/EDTA $/ \mathrm{H}_{2} \mathrm{O}_{2}$ system using the method of Elizabeth and Rao [13]. The reaction mixture contained $100 \mu$ of deoxyribose, $50 \mu \mathrm{l}$ of $\mathrm{FeCl}_{3}, 50 \mu \mathrm{l}$ of EDTA, $100 \mu \mathrm{l}$ of $\mathrm{H}_{2} \mathrm{O}_{2}$ and $100 \mu \mathrm{l}$ of ascorbic acid. Different concentrations of the sapogenin were added to $\mathrm{KH}_{2} \mathrm{PO}_{4} / \mathrm{KOH}$ buffer $(20 \mathrm{mM}$, $\mathrm{pH} 7.4$ ) to make it up to $1 \mathrm{ml}$. Incubation for 1 $\mathrm{h}$ at $37{ }^{\circ} \mathrm{C}$ resulted in the formation of thiobarbituric acid reactive substances (TBARS) measured spectrophotometrically at $532 \mathrm{~nm}$ following the method of Ohkawa et al [14]. The results were expressed as percent inhibition of TBARS and the amount of sample $(\mu \mathrm{g} / \mathrm{ml})$ producing $50 \%$ antilipid peroxidation was determined.

\section{Superoxide radical production}

The effect of total sapogenin on superoxide radical production (SRP) was evaluated following the nitroblue tetrazolium (NBT) reduction method of McCord and Friodovic [15]. The reaction mixture containing $0.5 \mathrm{mM}$ xanthine as substrate $(300 \mu \mathrm{L}), 1 \mathrm{mM}$ EDTA in phosphate buffer $(100 \mu \mathrm{L}), 0.05 \mathrm{mM}$ sodium cyanide $(100 \mu \mathrm{l}), 0.5 \mathrm{mM}$ xanthine oxidase $(20 \mu \mathrm{L})$, different concentrations of the sapogenin $(20 \mu \mathrm{l})$ and $0.1 \mathrm{mM}$ cytochrome $\mathrm{C}(300 \mu \mathrm{L})$ was placed in a $1 \mathrm{~cm}$ cuvette and the rate of increase in absorbance at $550 \mathrm{~nm}$ was recorded every minute for $5 \mathrm{~min}$. The results were calculated as amount of dismutase required to inhibit the rate of reduction of cytochrome $\mathrm{C}$ by $50 \%$ (i.e., to a rate of 0.0125 absorbance unit per minute which is defined as 1 unit of activity) and the amount of sample $(\mu \mathrm{g} / \mathrm{ml})$ producing $50 \%$ reduction of cytochrome $\mathrm{C}$ was determined.

\section{Effect on radiation-induced chromosomal aberrations in cultured human lymphocytes}

Fresh whole blood $(1.5 \mathrm{ml})$ was taken in different culture flasks and treated with 40, 55,75 and $100 \mu \mathrm{g} / \mathrm{ml}$ of total sapogenin in four different sets. One flask in each set was taken as vehicle control and treated with 75 $\mu \mathrm{l}$ of vehicle. All the culture flasks were incubated for $30 \mathrm{~min}$ and then each separate set of culture flasks was exposed to 1, 2, 3 and 4 Gy of $\gamma$-radiation. Triplicate cultures for each individual flask were set up by mixing $0.5 \mathrm{ml}$ of blood with $4.5 \mathrm{ml}$ of RPMl 1640 media. The culture flasks were coded and incubated at $37{ }^{\circ} \mathrm{C}$ in a humidified atmosphere of $5 \% \mathrm{CO}_{2}$. The cultures were harvested at $72 \mathrm{~h}$ for chromosomal studies. Air-dried preparations of hypotonically treated lymphocytes were made using routine techniques for chromosomal analysis as described by Moorhead et al [16]. Slides were prepared by air drying method and chromosomal aberrations were scored in conventional Giemsa-stained preparations as described by Lioyd et al [17].

\section{Media for blood culturing}

Blood samples were collected in heparinised sterile glass vials from the median cubital vein of a non-smoking healthy female donor of approximately 25 years. The whole blood $(0.5 \mathrm{ml})$ was incubated with $5 \mathrm{ml}$ of RPMI 1640 media containing $5 \%$ heat-inactivated faetal calf serum, penicillin $(100 \mathrm{U} / \mathrm{ml})$, streptomycin $(100 \mu \mathrm{g} / \mathrm{ml})$ and L-glutamine $(1.5 \mathrm{mg} / \mathrm{ml})$. An optimum concentration of phytohaemagglutinin $5 \mu \mathrm{g} / \mathrm{ml}$ was used to stimulate the lymphocytes to transform and divide in culture [18].

Trop J Pharm Res, December 2009; 8 (6):524 


\section{In-vitro radiation}

Theratron $780 \mathrm{C}$ cobalt teletherapy unit (Theratronics Limited, Canada) was used for radiating whole human blood samples at a dose rate of $1 \mathrm{~Gy} / \mathrm{min}$ in culture flasks (25 $\mathrm{cm}^{3}$ ), in a field size of $7 \times 20 \mathrm{~cm}^{2}$ which can accommodate 5 flasks at a time at a S.S.D (source surface distance) of $90-95 \mathrm{~cm}$.

\section{In-vitro cytotoxicity assay of the extract on murine $F_{1}$ B16 melanoma cell line}

Murine $F_{1} B 16$ melanoma cell line was used to study the in-vitro anti-cancer activity of total sapogenin. Male C $57 \mathrm{BL} / 6$ mice were used for in-vivo maintenance of cell line. Invitro harvesting of cells was carried out from a full-grown melanoma site $(2.5$ to $3 \mathrm{~cm})$ by aseptic transfer to collagen-coated culture flasks in Modified Eagle Minimum Essential Media containing $\mathrm{NaHCO}_{3}(220 \mathrm{mg} / 100 \mathrm{ml})$, which was supplemented with $10 \%$ heatinactivated faetal calf serum, L-glutamine $(300 \mu \mathrm{g} / \mathrm{ml})$ and $48 \mathrm{mg}$ gentamicin at $\mathrm{pH} 7.4$. The cells were expended in $75 \mathrm{~cm}^{2}$ tissue culture flasks at $37^{\circ} \mathrm{C}$ at an atmosphere of 5 $\% \mathrm{CO}_{2}$ in air (100\% humidity). A confluent monolayer was detached with $0.1 \%$ trypsin containing $0.02 \%$ EDTA in $\mathrm{Ca}^{2+}$ and $\mathrm{Mg}^{2+}$ free PBS $(\mathrm{pH} 7.4,0.01 \mathrm{M})$ and dissociated into a single-cell suspension for further cell culture. Serially cultured cell lines at $P_{3}$ to $P_{4}$ stages were used for cytotoxicity assay.

The assay was performed in collagen-coated radiation sterilised cell culture dishes $(2 \mathrm{ml}$ capacity, growth surface $60 \times 15 \mathrm{~mm}$ ). An amount of the cell culture $\left(2 \times 10^{4}\right.$ cells $\left./ \mathrm{ml}\right)$ was seeded and allowed to adhere by incubating for $6 \mathrm{~h}$ at $37^{\circ} \mathrm{C}$ in $5 \% \mathrm{CO}_{2}$. This method was standardised previously in the laboratory following the method of Umadevi et al [19]. After $6 \mathrm{~h}$, the cells were exposed to different concentrations of total sapogenin for a further $6 \mathrm{~h}$. The range of tested concentrations was from 10 to $500 \mu \mathrm{g} / \mathrm{ml}$ for total sapogenin and from 10 to $500 \mathrm{ng} / \mathrm{ml}$ for vincristin as positive control. Triplicate dishes were incubated for $72 \mathrm{~h}$ and cell viability was checked every $24 \mathrm{~h}$. The cells were detached by rinsing twice with trypsin, and then palleted by centrifugation; cell viability was measured by tryphan blue dye exclusion test and counted using WBC counting chamber of Neubauer's chamber. The $\mathrm{IC}_{50}$ (concentration at which cellular growth is inhibited by $50 \%$ ) was determined at $72 \mathrm{~h}$. The $\mathrm{IC}_{50}$ values were estimated from a plot of log total sapogenin concentration against percent cell viability.

\section{Ethical considerations}

The experimental protocol for animal studies was approved by the Institutional Animal Ethical Committee (ref no. Animal Eths. Comm./DB/304) prior to carrying out the experiments and the animals were handled as per the 'WHO guidelines for the care and use of animals in scientific research'.

\section{Statistical analysis}

All data are presented as mean \pm SEM. Experimental data were analysed using oneway ANOVA followed by Student's $t$-test. $\mathrm{P}<$ 0.05 was considered significant. Graph Pad Prism Version 3.02 software was used for statistical calculations.

\section{RESULTS}

\section{Identification of compound}

The leaf extract (yield: $10.8 \%$ ) was positive for reducing sugar, tannins, flavonoids, alkaloids, and triterpenoidal saponin but negative for glycoside and fixed oil. Hydrolysis of the extract followed by extraction with water-saturated n-butanol gave a brown coloured crude sapogenin mixture with a yield $2.4 \%$. Chromatographic elution of crude sapogenin with chloroform, chloroform/ethyl acetate (80: 20, 60: 40, 40: 60 and 20: 80), ethyl acetate and methanol produced five fractions. The fractions obtained were: Fraction-1 (mixture), Fraction2 (ENS-1) with $\mathrm{Rf}$ value of 0.385 , Fraction-3 (ENS-2) with Rf value of 0.360 , Fraction-4 
(no spot) and Fraction-5 (ENS-3) with Rf value of 0.314 .

Fraction 3 was positive for Salkowski and Noller's test and negative for Libermann Burchard test, indicating the presence of triterpene. The residue obtained was carefully crystallized on methanol gives a solid, white crystal $(232 \mathrm{mg})$, m.p. $116{ }^{\circ} \mathrm{C}$. UV $\delta \max _{2} 270$ $\mathrm{nm} ; \mathrm{IR}\left(\mathrm{KBr}, \mathrm{cm}^{-1}\right): 3400$ \& $1030(3-\beta-\mathrm{OH})$, 2923 \& 2854, 1637 (-C=C-), $1461 \& 1376$, 925, 862, 802 \& 723; ${ }^{1} \mathrm{H}$ NMR $\left(\mathrm{CDCl}_{3} 300\right.$ $\mathrm{MHz}): \delta 5.43(1 \mathrm{H}, \mathrm{t}, \mathrm{H}-24), 3.29(1 \mathrm{H}, \mathrm{m}, \mathrm{H}-$ 33) 1.62 (Me-26), 1.77 (Me-27), 0.74 (Me18), 0.85 (Me-19), 0.91 (Me-28), 1.16 (Me29), 1.21 (Me-30), 1.12 (Me-21); ${ }^{13} \mathrm{C}$ NMR $\left(\mathrm{CDCl}_{3} 75 \mathrm{MHz}\right): \delta 81.01$ (C-3), $135.62(\mathrm{C}-8)$, 37.26 (C-20), 129.20 (C-24), 20.18 (C-21), 17.52 (C-18), 21.14 (C-19), 18.72 (C-26), 27.32 (C-27), 17.78 (C-28), 26.56 (C-29), 30.14 (C-30); EIMS m/z (\%): $426\left(\mathrm{M}^{+}\right), 408$ $\left.\left(\mathrm{M}^{+}-\mathrm{H}_{2} \mathrm{O}\right), 2970.24 \% \mathrm{M}^{+}-\mathrm{H}_{2} \mathrm{O}-\mathrm{C}_{8} \mathrm{H}_{15}\right)$ and other fragments suggesting the fragmentation of side chain $111\left(16.42 \% \mathrm{C}_{8} \mathrm{H}_{15}\right), 97(25.08$ $\left.\% \mathrm{C}_{7} \mathrm{H}_{13}\right), 83\left(42.96 \% \mathrm{C}_{6} \mathrm{H}_{11}\right), 69(70.93 \%$ $\left.\mathrm{C}_{5} \mathrm{H}_{9}\right), 55\left(66.15 \% \mathrm{C}_{4} \mathrm{H}_{7}\right)$ and $41(100 \%$ $\mathrm{C}_{3} \mathrm{H}_{5}$ ). All the data's were compared with published data for Euphol from Kansui Radix as reported by Lin et al [20]. Thus fraction 3 was characterised as euphol $(8,24-$ Euphadien- 3 beta-ol; m.p. $116{ }^{\circ} \mathrm{C}$; yield $0.0232 \%$, fig. 1) based on IR and mass spectrometry.

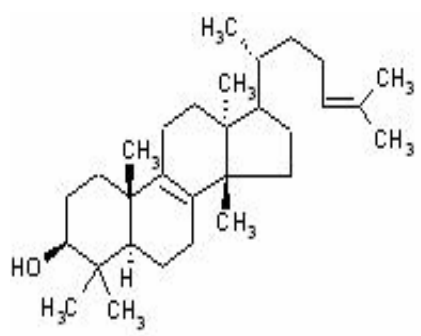

Fig. 1: 8, 24-euphadien- 3 beta-ol

\section{Antioxidant activity}

The in vitro antioxidant activities of the total sapogenin are depicted in Table 1.
Sapogenin, in the amounts used, showed moderate to high free radical scavenging activity and good hydrogen donating ability in relation to $\alpha$-tocopherol.

Table 1: Antioxidant activity of total sapogenin fraction of $E$. neriifolia leaf

\begin{tabular}{lcccc}
\hline & & \multicolumn{3}{c}{$\mathrm{IC}_{50}(\mu \mathrm{g} / \mathrm{ml})$} \\
\cline { 3 - 5 } Treatment & RPA & $\begin{array}{c}\text { HDA } \\
\text { (DPPH }\end{array}$ & HRSA & SRP \\
& ASE/mg & assay) & & \\
\hline$\alpha-$ & $447.70 \pm$ & $38.6 \pm$ & $34.2 \pm$ & $59.6 \pm$ \\
tocopherol & 6.21 & 0.7 & 0.4 & 1.0 \\
& & & & \\
Total & $190.36 \pm$ & 440.6 & $806.8 \pm$ & $471.3 \pm$ \\
sapogenin & 2.86 & \pm 42.3 & 57.9 & 38.2 \\
\hline
\end{tabular}

$n=9$ (experiments were repeated thrice, each time in triplicate). The $I C_{50}$ value was defined as the concentration $(\mu \mathrm{g} / \mathrm{ml})$ of the total sapogenin required for inhibiting the formation of free radicals by $50 \%$. Each experiment was carried out in triplicate and deviation of the absorbance value was less than $10 \%$.

\section{Effect of the extract on radiation-induced chromosomal aberrations}

Table 2 shows the effect of the extract on radiation-induced chromosomal aberrations of cultured human lymphocytes.

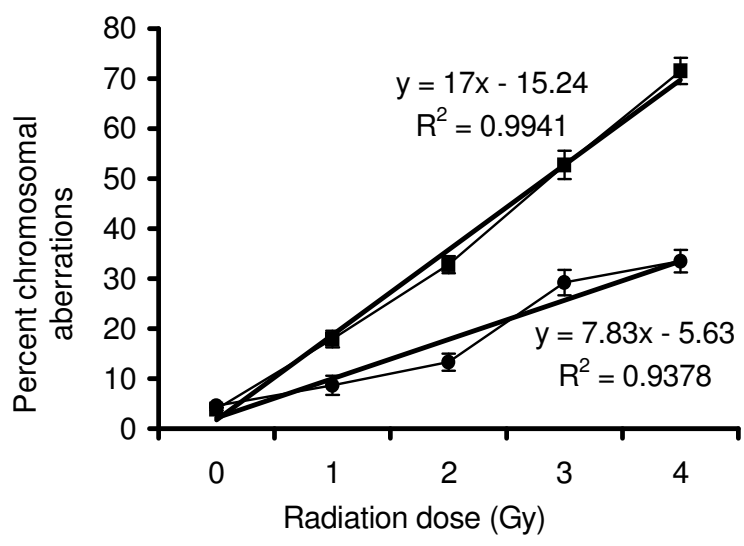

Fig 2: Dose-response curve for total chromosomal aberrations (\%) in cultured human peripheral lymphocytes treated with radiation alone and after pre-treatment with $75 \mu \mathrm{g} / \mathrm{ml}$ of $E$. neriifolia leaf total sapogenin $(\boldsymbol{\square}=$ radiation alone; $\bullet=$ radiation + total sapogenin) 
Table 2: Effect of total sapogenin of $E$. neriifolia leaf on radiation induced chromosomal aberrations in cultured human lymphocytes

\begin{tabular}{|c|c|c|c|c|c|c|c|c|c|}
\hline \multirow{3}{*}{$\begin{array}{l}\text { Radi- } \\
\text { ation } \\
\text { dose } \\
\text { (Gy) }\end{array}$} & \multirow[b]{3}{*}{$\begin{array}{l}\text { Treat- } \\
\text { ment } \\
(\mu \mathrm{g} / \mathrm{ml})\end{array}$} & \multirow[b]{3}{*}{$\begin{array}{l}\text { No. of } \\
\text { cells } \\
\text { scored }\end{array}$} & \multicolumn{5}{|c|}{ Chromosomal aberrations (\%) } & \multirow{2}{*}{\multicolumn{2}{|c|}{ Chromatid }} \\
\hline & & & \multicolumn{3}{|c|}{ Dicentric } & \multirow{2}{*}{$\begin{array}{l}\text { - Centric } \\
\text { rings }\end{array}$} & \multirow{2}{*}{$\begin{array}{l}\text { Excess } \\
\text { acentrics }\end{array}$} & & \\
\hline & & & $\begin{array}{l}\text { Frag- } \\
\text { ments }\end{array}$ & $\begin{array}{l}\text { Without } \\
\text { fragments }\end{array}$ & $\begin{array}{l}\text { Inter- } \\
\text { change }\end{array}$ & & & breaks & gaps \\
\hline- & Control & 470 & 1.4 & 0.0 & 0.0 & 0.0 & 2.5 & 0.0 & 0.4 \\
\hline- & 75 & 500 & 1.6 & 0.2 & 0.0 & 0.0 & 2.8 & 0.0 & 0.5 \\
\hline \multirow[t]{5}{*}{1} & Control & 532 & 6.7 & 0.3 & 2.3 & 1.4 & 5.2 & 0.2 & 1.3 \\
\hline & 40 & 586 & 5.2 & 0.3 & 2.1 & 1.2 & 4.6 & 0.2 & 1.2 \\
\hline & 55 & 725 & 3.7 & 0.2 & 1.4 & 1.0 & 3.5 & 0.0 & 1.2 \\
\hline & 75 & 658 & 3.2 & 0.0 & 0.9 & 0.6 & 3.1 & 0.0 & 0.8 \\
\hline & 100 & 564 & 3.5 & 0.0 & 1.1 & 0.8 & 3.2 & 0.0 & 0.8 \\
\hline \multirow[t]{5}{*}{2} & Control & 536 & 9.4 & 0.6 & 4.5 & 2.8 & 8.5 & 0.6 & 1.9 \\
\hline & 40 & 513 & 8.3 & 0.6 & 4.2 & 2.0 & 6.0 & 0.4 & 1.8 \\
\hline & 55 & 672 & 5.5 & 0.4 & 3.2 & 1.7 & 5.3 & 0.2 & 1.4 \\
\hline & 75 & 651 & 4.1 & 0.2 & 2.9 & 1.3 & 4.2 & 0.2 & 1.3 \\
\hline & 100 & 543 & 4.2 & 0.2 & 3.2 & 1.3 & 4.4 & 0.2 & 1.4 \\
\hline \multirow[t]{5}{*}{3} & Control & 995 & 18.1 & 1.6 & 12.4 & 5.8 & 12.8 & 0.8 & 2.7 \\
\hline & 40 & 578 & 12.3 & 1.4 & 9.8 & 4.1 & 10.4 & 0.5 & 2.2 \\
\hline & 55 & 733 & 10.0 & 1.1 & 7.8 & 3.5 & 8.7 & 0.5 & 1.8 \\
\hline & 75 & 680 & 9.9 & 0.7 & 7.0 & 2.6 & 8.0 & 0.3 & 1.5 \\
\hline & 100 & 570 & 10.3 & 0.8 & 7.0 & 2.5 & 8.3 & 0.3 & 1.6 \\
\hline \multirow[t]{5}{*}{4} & Control & 520 & 24.2 & 2.7 & 18.6 & 7.9 & 15.1 & 1.8 & 4.3 \\
\hline & 40 & 544 & 20.6 & 2.2 & 12.3 & 6.4 & 12.9 & 1.4 & 3.4 \\
\hline & 55 & 659 & 13.6 & 1.5 & 9.0 & 4.1 & 8.3 & 0.9 & 2.3 \\
\hline & 75 & 712 & 10.2 & 1.2 & 8.7 & 3.5 & 6.9 & 0.6 & 1.8 \\
\hline & 100 & 375 & 12.3 & 1.3 & 8.6 & 3.7 & 7.2 & 0.6 & 2.0 \\
\hline
\end{tabular}

Control samples were incubated without any treatment. These data show the effect of the leaf total sapogenin treatment $(40-100 \mu \mathrm{g} / \mathrm{ml})$ as well as the effect of different doses of radiation (1 - $4 \mathrm{~Gy}$ ) on chromosomal aberrations in cultured normal non-malignant cells (human lymphocytes).

Pre-treatment with $75 \mu \mathrm{g} / \mathrm{ml}$ of total sapogenin fraction reduced total chromosomal aberrations to $33.5 \%$ compared to $71.5 \%$ for radiation treatment (RT) alone at 4 Gy. The slope of the linear dose-response curve for total sapogenin treatment was 7.83 , which is significantly $(p<$ 0.001 ) lower than that of the radiation only treated group (see Figure 2).

\section{Cytotoxicity assay on murine $F_{1}$ B16 Melanoma cell line}

In-vitro testing of total sapogenin against the murine $\mathrm{F}_{1} \mathrm{~B} 16$ Melanoma cell line showed $76.6 \%$ cell viability at $10 \mu \mathrm{g} / \mathrm{ml}$ compared to
$13.6 \%$ at $500 \mu \mathrm{g} / \mathrm{ml}$ of total sapogenin, with control as $100 \%$ cell viability, as shown in Figure 3(A). Figure 3(B) shows the plot of log total sapogenin concentration against cell viability (probit scale) with a best-fit linear regression curve (slope: 0.9415) superimposed. The assay data show that the $\mathrm{IC}_{50}$ (over a period of $72 \mathrm{~h}$ ) concentration of total sapogenin that inhibited growth of mouse melanoma cells by $50 \%$ was 173.78 $\mu \mathrm{g} / \mathrm{ml}$ compared to $120 \mathrm{ng} / \mathrm{ml}$ for vincristin.

\section{DISCUSSION}

Plants are valuable sources of novel biologically active molecules. Saponins are 
high molecular weight compounds comprising glycosides with a sugar moiety linked to a triterpene or steroid aglycone. Triterpene saponins, particularly, have been the subject of much interest because of their biological properties.

Free radical damage to biosystems is one of the major processes that contribute to degenerative diseases such as cancer and ageing. Free radical scavengers protect cellular DNA against indirect effects of ionizing radiation where hydroxyl radicals are believed to be the primary active species responsible for the damage [21]. The data obtained in this study demonstrate the antioxidant activity of the sapogenin isolated from the leaf extract of $E$. neriifolia. The good reducing power of sapogenin means that triterpenoidal compounds, especially euphol, are electron donors, and therefore, can act as antioxidants [22]. Hydrogen donating ability is an index of primary antioxidants. DPPH is known to abstract labile hydrogen and the ability to scavenge the DPPH radical is related to the inhibition of lipid peroxidation [23]. Total sapogenin inhibits oxygen derived free radicals such as superoxides and hydroxyl radical in vitro with a relatively moderate potency. Terpenes and bioflavones isolated from Ginko biloba inhibited lipid peroxidase and superoxide anion in hepatocytes that are generally implicated in cell damage [24]. There is a good correlation between antioxidant properties and radioprotection by flavonoids as they could prevent the accumulation of DNA damage induced by UV radiation. Castilla et al [25] has demonstrated the antioxidant as well as radioprotective effects of flavon-3-ol from grape seeds against chromosomal damage induced by $x$-rays.

Peripheral blood lymphocytes (PBL) are extensively used in biomonitoring of populations exposed to various mutagenic or carcinogenic compounds because the sensitivity of this system in detecting chromosome damage induced by exposures of ionising radiation. $\gamma$-radiation produces morphological changes in lymphocytes by decaying their proliferation, which indirectly defines genomic instability. $\gamma$-rays generate hydroxyl radicals in cells and induce DNA damage that leads to mutations and chromosomal aberrations [26]. Total sapogenin at a concentration of $75 \mu \mathrm{g} / \mathrm{ml}$ significantly decreased total chromosomal aberration. The results signify that the sapogenins reduced gamma radiationinduced genomic instability by reducing chromosomal aberrations due to the presence of antioxidants.

Total sapogenin exhibits cytotoxic activity on murine $F_{1}$ B16 Melanoma cell line. It showed apparently high $I_{50}$ as the cells were exposed to extracts only for a short duration of $6 \mathrm{~h}$. Using conventional cytotoxic tests, the cells were exposed to cytotoxic chemical for $72 \mathrm{~h}$ where cytotoxicity may be partly due to cumulative accumulation of the drugs in the culture media.

Saponins have many kinds of biological activities such as anti-bacterial, anti-viral, anti-tumour, anti-fertility, anti-inflammatory, anti-hyperlipidemic, anti-hypertension, antihyperglycaemic and immunoregulatory, etc.

Furthermore, triterpenoids exert physiological activities in the cardiovascular, nervous and, adrenocortical systems as well as enzymatic activity, and therefore, are frequently a subject of research in natural medicine. The total triterpenoidal sapogenin extracted from bamboo (Phyllostachys Sieb. et Zucc) were reported to exhibit pharmacological activities such as anti-free radical, anti-oxidation, antitumour and anti-hypertension [27]. Triterpene alcohols such as ursolic and oleanolic acids are said to exert antitumour effect on lung, 
(A)

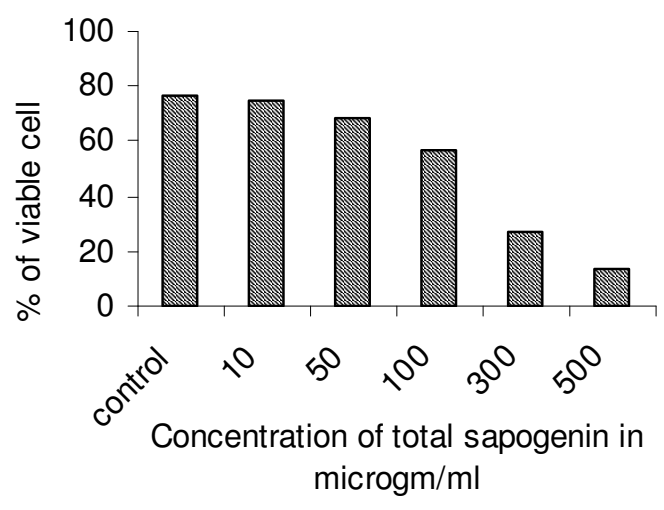

(B)

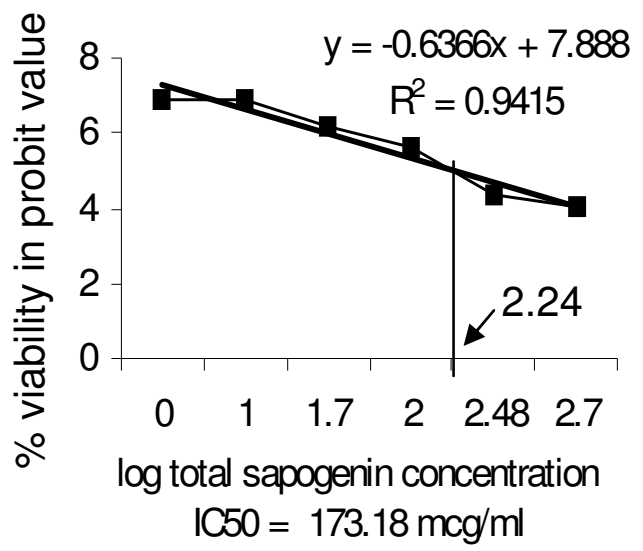

Figure 3: Viability (\%) of F1 B16 melanoma cells after $72 \mathrm{~h}$ of in-vitro culture growth with different concentrations of $E$. neriifolia leaf total sapogenin $(A)$; Inhibitory profile of $E$. neriifolia leaf total sapogenin treatment on in-vitro growth of $\mathrm{F} 1 \mathrm{~B} 16$ melanoma cells after $72 \mathrm{~h}$ of culture (B). $\mathrm{IC}_{50}=$ $173.78 \mu \mathrm{g} / \mathrm{ml}$ (antilog of 2.24).

breast and colon tumours [28]. Topical application of euphol isolated from roots of Euphorbia kansui markedly suppressed the tumour-promoting effect of 12-Otetradecanoylphorbol-13-acetate in two-stage carcinogenesis in mouse $s$ kin initiated with 7, 12-dimethylbenz[a] anthracene [3].

\section{CONCLUSION}

E. neriifolia Leaf is rich in crude sapogenin, and euphol $(0.023 \%)$ was identified as a major constituent. The sapogenin fraction showed antioxidant, radioprotective and cytotoxic activity against malignant melanoma cells. Our study supports the use of $E$. neriifolia as an antitumour herbal remedy in Indian traditional medicine. This study reports for the first time the potential anticancer properties of $E$. neriifolia triterpenes. However, the sapogenin content needs to be studied further to isolate other active constituents and to elucidate its in-vivo anticancer activity profile; this further work is in progress in our laboratory.

\section{ACKNOWLEDGEMENT}

The authors are grateful to All India Council of Technical Education, New Delhi, for financial assistance through the award of a National Doctoral Fellowship to one of the authors (PB) (grant no. FD/NDFS/2003-04). We also express our gratitude to Drs $P$ Uma Devi and N Ganesh, and all the research staff of Jawaharlal Nehru Cancer Hospital and Research Center, Bhopal, for their assistance, support and valuable suggestions.

\section{REFERENCES}

1. Anonymous. The Wealth of India: Raw Material. Vol. III (D-E), New Delhi, Council of Scientific and Industrial Research Publication, 1952, pp 226.

2. Kupchan SM, Uchida I, Branfman AR, Dailey RG Jr, Fei BY. Antileukemic principles isolated from euphorbiaceae plants. Science 1976; 191(4227): 571-572.

3. Yasukawa K, Akihisa T, Yoshida ZY. Inhibitory effect of euphol, a triterpene alcohol from the roots of Euphorbia kansui, on tumor promotion by 12-o-tetradecanoylphorbol- 13-acetate in two-stage carcinogenesis in mouse skin. J Pharm Pharmacol., 2002; 54(1): 119-124. 
4. Bigoniya P, Rana AC. Psychopharmacological profile of hydro-alcoholic extract of Euphorbia neriifolia leaves in mice and rats. Indian J Exp Biol., 2005; 43: 859-862.

5. Bigoniya $P$, Rana AC. Wound healing activity of Euphorbia neriifolia leaf extract. J Nat Remedies 2007; 7(1): 94-101.

6. Bigoniya $P$, Rana AC. Immunomodulatory activity of Euphorbia neriifolia leaf hydro-alcoholic extract in rats. Ind Drugs 2008; 45(2): 90-97.

7. Bigoniya $P$, Rana AC. Hemolytic and In-vitro Antioxidant Activity of Saponin Isolated from Euphorbia neriifolia Leaf. In: Recent Progress in Medicinal Plants, Natural Products - II, vol 2, Chapter-20, 2006, pp 359-376.

8. Brain KR, Turner TD. The Practical Evaluation of Phytopharmaceuticals. Bristol, WrightScientenica, 1975, pp 153.

9. Shellard EJ. Practical Plant Chemistry for Pharmacy Students. London, Pitman Medical Publishing Co. Ltd., 1957, pp 34-80.

10. Hawk PB, Oster BL, Summerson WH. The Practical Physiological Chemistry. $13^{\text {th }}$ ed, New York, McGraw Hill Book Co., 1954, pp 111.

11. Oyaizu M. Studies of products browning reaction: Antioxidative activity of products of browning reaction prepared from glucosamine. Jpn $J$ Nutr., 1986; 44: 307-315.

12. Hatano $T$, Kagawa $H$, Yasuhara T, Okuda T. Two new flavonoids and other constituents in cicore root: their relative astringency and radical scavenging effects. Chem Pharm Bull., 1988; 36: 2090-2097.

13. Elizabeth $K$, Rao MNA. Oxygen radical scavenging activity of curcumin. Int J Pharm., 1990; 58: 237-240.

14. Ohkawa $H$, Ohishi $N$, Yagi K. Assay for lipid peroxidation in animal tissue by thiobarbituric acid reaction. Anal Biochem., 1979; 95: 351 358.

15. McCord JM, Fridovich I. Superoxide dismutase: An enzymic function for erythrocuprein (hemocuprein). J Biol Chem., 1969; 224: 60496055.

16. Moorhead PS, Nowell PC, Meliman WJ, Battip PMC, Hungerford DA. Chromosome preparations of leukocytes cultivated from human peripheral blood. Exp Cell Res., 1960; 20: 613-617.

17. Lioyd DC, Purrott RJ, Prosser JS. The study of chromosomal aberration yield in human lymphocytes as an indicator of radiation dose: Revised Technique, National Radiological Protection Board. Technical Memorandum NRPB-M70: Chilton, Didcot, Oxon, Great Britain, 1982.
18. Fenech $M$, Morley AA. Cytokinesis-block micronucleus method in human lymphocytes: effect of in vivo ageing and low dose $x$ irradiation. Mutation Res., 1986; 161: 193-198.

19. Uma Devi $P$, Nagarathnam $A$, Rao BSS. Introduction to radiation biology. New Delhi, B.I Churchill Livingstone Pvt. Ltd., 2000, pp 226227.

20. Lin JH, Ku YR, Lin YZ, Teng SF, Wen KC, Liao CH. Preparative isolation and gas chromatographymass spectrometry analysis of trterpenoids in kansui radix. J Food Drug Anal., 2000; 8(4): 278-282.

21. Sasaki MS, Matsubara S. Free radical scavenging in protection of human lymphocytes against chromosome aberration formation by gammaray irradiation. Int $J$ Radiat Biol., 1977; 32: 439-445.

22. Yen GC, Chen HY. Antioxidant activity of various tea extracts in relation their antimutagenicity. $J$ Agric Food Chem., 1995; 43: 27-32.

23. Matsubara $N$, Fuchimoto $S$, Iwagaki $H$, Nonaka $Y$, Kimura T, Kashino $H$, Edamatsu R, Hiramatsu $M$, Orita $K$. The possible involvement of free radical scavenging properties in the action of cytokines. Res Commun Chem Pathol Pharmacol., 1991; 71: 239-242.

24. Joyeux $M$, Lobstein $A$, Anton $R$, Mortier $F$. Comparative antilipidperoxidant, antinecrotic and scavenging properties of terpenes and bioflavones from Ginko and flavonoids. Planta Med., 1995; 61: 126-129.

25. Castilla J, Benavente-Garcia O, Lorente J, Alcaraz $M$, Redondo $A$, Ortuno $A$, Del-Rio JA. Antioxidant activity and radioprotective effects against chromosomal damage induced in vitro by $X$-rays of flavan-3-ols (procyanidins) from grape seeds (Vitis vinifera): comperative study versus other phenolic and organic compounds. J Agri Food Chem., 2000; 48: 1738-1745.

26. Riley $P A$. Free radicals in biology: oxidative stress and the effects of ionizing radiation. Int $J$ Radiat Biol., 1994; 65: 27-33.

27. Ying Z, Xiaoqin W, Zhuoyu Y, Yunlong Z, Lingen C, Shenggen L. Composition containing total triterpenoid saponins extracted from bamboo, and the preparation method and use thereof, United States Patent 20060148733, 2006. http://www.freepatentsonline.com/y2006/0148 733. html. Accessed $2^{\text {nd }}$ May, 2007.

28. Haridas V, Gutterman JU. Triterpene compositions and methods for use thereof, United States Patent 6962720, 2002. http://www.freepatents online.com/6962720.html. Accessed $7^{\text {th }}$ August, 2007. 